\title{
Investigating the Efficiency of Monetary Transmission Channels in Serbia
}

Article history:

Received: 15 March 2014

Sent for revision: 6 April 2014

Received in revised form: 6 May 2014

Accepted: 9 June 2014

Available online:1 July 2014

\begin{abstract}
The aim of this paper is to evaluate the effectiveness of monetary policy transmission mechanism in Serbia. By using Johansen cointegration technique, based on VAR/VECM methodology, the impact of selected monetary variables on real economic activity and price level is studied over the period 2007M1-2014M1. Results indicate that the exchange rate passthrough to both output and prices is relatively strong, while the interest rate channel is still underdeveloped and does not appear to play an important role as a monetary transmission mechanism. Such balance of powers is not unexpected having in mind traditionally powerful nexus between exchange rate movements and behavior of all economic agents in Serbia. On the other hand, it should be stressed that a very weak link revealed between key policy interest rate and prices in Serbia does not represent a desirable feature in the adopted inflation targeting regime.
\end{abstract}

Keywords: Monetary transmission channels, exchange rate, interest rate, real economic activity, price level, Serbia

\section{Istraživanje efikasnosti kanala monetarnog prenosa u Srbiji}

Apstrakt: Cilj ovog rada je istraživanje efikasnosti transmisionog mehanizma monetarne politike u Srbiji. Korišćenjem Johansenovog pristupa kointegraciji, zasnovanog na VAR/VECM metodologiji, uticaj odabranih monetarnih varijabli na realnu ekonomsku aktivnost i nivo cena proučavan je u periodu od januara 2007. do januara 2014. godine. Rezultati ukazuju da je prenos deviznog kursa na proizvodnju i cene relativno snažan, dok je kanal kamatne stope još uvek nedovoljno razvijen i ne igra značajnu ulogu u procesu monetarne transmisije.

\footnotetext{
${ }^{1}$ University of Novi Sad, Faculty of Economics Subotica, PhD student, gonguly@gmail.com
} 
Jevđović G.: Investigating the Efficiency of Monetary Transmission Channels in Serbia

Takav odnos snaga je zapravo i očekivan, imajući u vidu tradicionalno snažne veze između kretanja deviznog kursa i ponašanja svih ekonomskih subjekata u Srbiji. Sa druge strane, potrebno je naglasiti da veoma slaba veza otkrivena između referentne kamatne stope i nivoa cena u Srbiji ne predstavlja poželjnu karakterisitiku u usvojenom režimu targetiranja inflacije.

Ključne reči: Kanali monetarne transmisije, devizni kurs, kamatna stopa, realna ekonomska aktivnost, nivo cena, Srbija

\section{Introduction}

Monetary transmission mechanism refers to the process through which monetary policy affects the real economy, especially the key macroeconomic variables such as aggregate demand, output and prices. Mechanism of monetary transmission is very complex since it is composed of multiple parallel channels with different and varying time lags to the change in the instrument controlled by the monetary authority. Also, transmission channels have various importance in the pass-through of impulses derived from the same instrument of monetary policy in both different countries and different periods of development within the same country. As emphasized by Bernanke \& Gertler (1995) they are a kind of monetary policy "black box". Accordingly, investigating the efficiency of monetary transmission channels is of great importance since a good knowledge of their characteristics, strengths and weaknesses is an important prerequisite for effective stabilization measures. Furthermore, as stressed by Cevik \& Teksoz (2012) gathering evidence on the efficiency of monetary policy transmission remains a priority, especially in the aftermath of the global economic crisis, which has certainly disrupted some of the channels.

While there is ample theoretical and empirical literature on how monetary shocks affect macroeconomic aggregates in developed economies with wellfunctioning financial markets little is known about this process in the case of Serbia. Therefore, the purpose of this paper is to provide an empirical analysis of the efficiency, significance and modus operandi of various conventional channels of monetary policy transmission on real economic activity and price level in domicile conditions. To this end, Johansen cointegration procedure and vector error correction modeling (VECM) was employed.

The remainder of this paper is organized as follows. Section 2 provides an overview of related empirical literature. Section 3 presents research hypotheses and section 4 introduces empirical methodology. Section 5 describes time series used in the analysis. Finally, section 6 presents results 
Jevđović G.: Investigating the Efficiency of Monetary Transmission Channels in Serbia

and discussion. Conclusion circles important findings arising from the research.

\section{Literature Review}

Interest in exploring the nexus between monetary policy and real sector has given rise to a large body of theoretical literature and to global profusion of empirical papers that seek to match theory with real data. However, empirical results for the Republic of Serbia are both less numerous and less robust.

Exchange rate to inflation pass-through in Serbia is investigated by Vilaret \& Palić (2006). Using 2001 to 2006 sample period and ADL and recursive VAR methodologies, their analysis confirms that the exchange rate pass-through effect in Serbia has been relatively high but, like in most transition countries, incomplete and well below one. In general, their estimates of a short-term pass-through elasticity are below 0,3 and those of a long-term pass-through are below 0,6 . Using the same methodology and a bit extended sample, Tasić (2008) reports exchange rate to prices pass-through ratios ranging from 0,13 to 0,31 for the short-run, and between 0,19 and 0,50 for the long-run.

As far as interest rate channel is concerned, an attempt is made to evaluate the strength of what is in practice the first part of the transmission process, which involves the pass-through from the policy rate to the key interest rates of the economy. Results obtained by Aleksić, Đurđević, Palić \& Tasić (2008) suggest that this part of the interest rate channel in Serbia is shaded, and highly dependent on the degree of dollarization. Maximum potential passthrough is between 0,169 and 0,820 , depending on the model specification. However, the second stage of transmission (how changes in the money market rate affect output and inflation) has not been examined.

Josifidis, Allegret \& Beker-Pucar (2009) investigate both exchange rate and interest rate pass-through to consumer prices with variance decomposition of VAR/VEC model on the example of four (former) transition economies Poland, Czech Republic, Slovakia and the Republic of Serbia. In the case of Serbia, authors conclude that the dominant transmission channel is the exchange rate channel. In line with that, they warn that "strong exchange rate pass-through, weak interest rate pass-through and dominant direct managing of the exchange rate fluctuations are not good prerequisites for successful managed floating and inflation targeting regimes" (Josifidis et al., 2009, p.213214).

Channels of monetary transmission have been extensively studied in neighboring Croatia. According to results obtained by Lang \& Krznar (2004) by using structural VAR model, the long-term depreciation leads to a decline 
in economic activity, approximated by industrial production. Vizek (2006) finds evidence that the industrial production in Croatia is very sensitive to exchange rate movements. By employing vector autoregression Doležaj (2011) also concludes that the exchange rate channel is the dominant way of monetary transmission on real economic activity in Croatia, and once again that it works in an unconventional way - the exchange rate depreciation leads to a decline in real economic activity. However, these results are not in line with economic theory, according to which the national currency depreciation in the long run leads to an expansion of economic activity, through the mechanism of increase in net exports. Nevertheless, as alleged by Kamin, Turner \& Van't Dack (1998) mentioned unconventional findings are typical for economic systems in which the exchange rate serves as the nominal anchor.

Vizek (2006), and later Doležaj (2011), find statistically significant but rather weak long-term effect of money supply on economic activity in Croatia. On the other hand, Erjavec \& Cota (2003) conclude that the money supply is neutral in the short run. Finally, the vast majority of empirical research in Croatia could not find any evidence of the interest rate channel significance. Vizek (2006) explains this with insufficient sensitivity of the economy to interest rate movements. Yet, Tkalec \& Vizek (2009) determine some impact of interest rates on industrial production, emphasizing that this effect is fairly weak and very delicate since it is observed only in certain industries. On the other hand, by using more recent data compared to previous studies, Doležaj (2011) finds statistically significant impact of interest rate on the real economic activity, approximated by the index of industrial production. Although the identified influence has an unusual direction and is additionally of quite weak intensity, these findings certainly represent an evidence of the evolution of monetary transmission mechanism in Croatia.

A number of studies in Croatia also find evidence that certain monetary variables significantly affect the price level. Billmeier \& Bonato (2002) come to the conclusion that there is a long-term cointegration relationship between exchange rate and inflation in Croatia, and that national currency depreciation causes a rise in price level. In contrast, some other studies (Vizek \& Broz (2009) and Malešević-Perović (2009) for instance) report that currency depreciation tends to lead to a decline in inflation. Vizek \& Broz (2009) explain this unusual direction of the exchange rate to prices pass-through by excessive reaction of monetary policy on depreciation pressures, due to the so-called "fear of floating", which leads to contraction in prices.

Numerous studies have examined the efficiency of monetary transmission within the EU. For instance, Peersman \& Smets (2001b) use VAR model on synthetic data for investigating the efficiency of monetary transmission mechanisms in the EU-15. Results indicate that an increase in interest rate is followed by the real currency appreciation and decline in real economic 
activity, predominantly as a result of contraction in investment and only slightly due to the fall in private consumption. Interestingly, same authors but in another paper (Peersman \& Smets, 2001a), conclude that the effects of monetary policy are stronger in times of recession than in the expansion phase.

Lovrinović \& Benazić (2004) analyze monetary transmission in the EU, but focus only on the interest rate channel. Results of their investigation confirm the initial hypothesis that an increase in interest rate leads to a decrease in industrial production, growth of retail prices and finally, to appreciation of the real exchange rate. Van Els, Locarno, Morgan \& Villetelle (2001) study monetary transmission channels in the EU with large structural macro models available to the European Central Bank and central banks of the European Monetary System. Authors find that in the first two years after the monetary shock exchange rate represents the most powerful channel while, starting from the third year, interest rate channel becomes the dominant form of monetary transmission.

Chatelain, Generale, Hernando, Kalckreuth \& Vermeulen (2001) approach to monetary transmission is in some way different. Namely, they examine the sensitivity of investment spending to interest rate movements in companies of four largest EU countries (Germany, Italy, France and Spain). Results indicate that investment is extremely sensitive to changes in the cost of capital in all four countries, which actually implies a strong influence of the interest rate channel on economic activity.

By employing Granger causality tests, Ganev, Molnar, Rybinski \& Wozniak (2002) examine the characteristics of both exchange rate and interest rate pass-through on economic activity in ten Central European countries (Bulgaria, Czech Republic, Estonia, Hungary, Latvia, Lithuania, Poland, Romania, Slovenia and Slovakia). According to the findings of this study, in most countries exchange rate channel has greater and more stable effect on the economic activity compared to the interest rate channel. Furthermore, exchange rate pass-through has the expected conventional direction depreciation of the national currency leads to an expansion of economic activity.

Finally, Jarocinski (2008) analyzes the similarities and differences in channels of monetary transmission in five old EU countries (France, Italy, Spain, Portugal and Finland) and four new ones (Hungary, Czech Republic, Poland and Slovenia). The author concludes that the transmission process is similar in the qualitative sense for both groups of countries, with some interesting disparities that are primarily related to the reaction of prices to monetary shocks, which tend to be more pronounced in the new member states. 
An interesting comparative study of the effectiveness of monetary transmission in unofficially dollarized (Uruguay and Peru) and non-dollarized economies (Chile and New Zealand), under the inflation targeting regime, is carried out by Acosta-Ormaechea \& Coble (2011). Results reveal that the interest rate channel is more effective in non-dollarized economies while the exchange rate pass-through is more relevant in cases of highly unofficially dollarized economies of Peru and Uruguay.

To sum up, it seems that empirical evidence has shown that the interest rate channel is usually the most important transmission mechanism in advanced economies with developed financial markets, while the exchange rate passthrough is generally the dominant way of monetary transmission in emerging market economies, which are often also exposed to a significant degree of dollarization/euroization. Also, as highlighted by Cevik \& Teksoz (2012), the exchange rate channel appears to be particularly important in small open economies with flexible exchange rates.

\section{Research Methodology}

\subsection{Hypothesis}

In line with the purpose of research, but also considering related empirical work, in this paper following hypotheses have been tested:

$\mathrm{H} 1$ : There is a long-term equilibrium relationship between selected monetary variables (exchange rate, key policy interest rate and money supply) and real economic activity i.e. price level in Serbia.

Taking into account theoretical foundations of monetary transmission mechanism, as well as relevant empirical investigation, it is intuitive to expect that there is a long-term equilibrium relationship between monetary variables and real sector in Serbia. Also, having in mind the structure of domicile economy, (under)development of financial markets and the presence of high degree of unofficial euroization, it is anticipated that, in terms of strength and efficiency of transmission channels, Serbia does not differ much from the experiences of other developing CEE countries. In other words, it is expected that, apart from the direct channel, the greatest importance in the monetary transmission process will belong to the exchange rate channel.

$\mathrm{H} 2$ : In both short and long run exchange rate channel is superior to the interest rate channel in Serbia.

Emphasizing the importance of exchange rate pass-through in domicile conditions is reinforced by the fact that changes in the exchange rate have been traditionally, for almost three decades, a strong signal for the behavior of 
all economic agents in Serbia. In addition, as outlined in Josifidis et al. (2009) exchange rate is a natural anchor in transition economies having in mind (hyper) inflationary past. When it comes to the direction of the exchange rate pass-through on real economic activity and price level in Serbia preliminary hypothesis have not been set. However, it should not come as a surprise if unconventional direction of the exchange rate channel is revealed.

\subsection{Method}

The idea underlying the concept of cointegration is appealing for describing many economic phenomena, including the one in the essence of this paper. Figuratively, the concept of cointegration assumes that there are two or more time series, each of which has a stochastic trend, but whose movements in time occur within certain limits, meaning that time series do not drift too much from each other. As stated in Mladenović \& Nojković $(2011,2012)$, this can be explained by the existence of certain "force of attraction", embedded in the character of the economy, that "draws" time series one to another. More formally, two time series that are integrated of the first or some higher order, are said to be cointegrated if there exists a stationary linear combination of them. Cointegrated variables may deviate from their relationship in the short run, but over the long-term they move within their equilibrium relations.

For examination of possible cointegrating relationship between selected variables, in this paper Johansen procedure (Johansen, 1988; Johansen \& Juselius, 1990; Johansen, 1991; Johansen \& Juselius, 1992) is employed. Johansen's approach to cointegration, based on vector autoregressive model (VAR hereafter) and vector error correction model (VECM hereafter) is widely used for various empirical investigation, and is more preferable than alternatives, for instance Engel-Granger two-step method that suffers from serious deficiencies.

For $n$ variables $(n \geq 2)$ that are integrated of the first order a VAR with $k$ lags could be set up:

$$
\begin{aligned}
& y t=\beta_{1} \cdot y_{t-1}+\beta_{2} \cdot y_{t-2}+\ldots+\beta_{k} \cdot y_{t-k}+u_{t}
\end{aligned}
$$

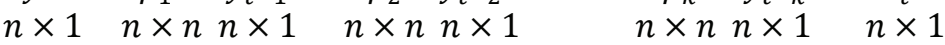

For the above VAR (1) there is a VECM representation of the following form:

$\Delta y_{t}=\Pi \cdot y_{t-k}+\Gamma_{1} \cdot \Delta y_{t-1}+\Gamma_{2} \cdot \Delta y_{t-2}+\cdots+\Gamma_{k-1} \cdot \Delta y_{t-(k-1)}+u_{t}$

where $\Pi=\left(\sum_{i=1}^{k} \beta_{i}\right)-I_{g}$ and $\Gamma_{i}=\left(\sum_{j=1}^{i} \beta_{j}\right)-I_{g}$

The Johansen procedure centers around the examination of the rank of the $\Pi$ matrix, which is equal to the number of its characteristic roots (eigenvalues, denoted as $\lambda$ ) that are different from zero. If variables are not cointegreted the rank of $\Pi$ will be zero, i.e. $\lambda_{\mathrm{i}}=0$ for every $i$. For $\Pi$ to have a rank of 1 , the 
largest eigenvalue must be significantly non-zero, while others should not differ much from zero.

Johansen proposes two different likelihood ratio tests for determining the rank of the $\Pi$ matrix: the trace test and the maximum eigenvalue test. The first test ( $\lambda$ trace) has as its null hypothesis that the number of cointegrating vectors is less than or equal to $r$, against an unspecified or general alternative that there are more than $r$. The second one ( $\lambda$ max) involves the null hypothesis that the number of cointegrating vectors is $r$ against an alternative of $r+1$. Relevant test statistics are formulated as:

$\lambda_{\text {trace }}(r)=-T \sum_{\mathrm{i}=\mathrm{r}+1}^{\mathrm{n}} \ln \left(1-\lambda_{i}\right)$

$\lambda_{\max }(r, r+1)=-T \ln \left(1-\lambda_{r+1}\right)$

where $r$ is the number of cointegrating vectors and $\lambda_{i}$ is the estimated value for the i-th order eigenvalue.

After determining the rank of the matrix, cointegrating vectors are identified, and normalized in relation to the variable of interest. Following that, error correction model is derived and speed of adjustment coefficients is analyzed. Finally, diagnostic checks and parameter stability tests are conducted.

\subsection{Data}

Analysis of the efficiency of monetary transmission in Serbia refers to monthly data for the period January 2007 - January 2014. Following economic variables are used for modeling:

- Exchange rate dinar per euro (period average) - variable ER,

- National Bank of Serbia key policy rate - variable IR,

- Money supply M1 - variable M,

- Index of industrial production (base year 2010) - variable IND,

- Consumer price index (base year 2010) - variable CPI.

The data source for the variable IND is the official webpage of Eurostat, whereas data for variables $M$, ER and IR are obtained from the official webpage of the National Bank of Serbia. The data source for variable CPI is the official webpage of the Statistical Office of the Republic of Serbia. Time series with nominal values are deflated by consumer price index. All time series, except interest rate, are logarithmically adjusted, in order to stabilize the variance. Moreover, in order to focus as much as possible on monetary variables, that is, to exclude any possible fiscal influence from the analysis, two dummy variables are introduced. Namely, variables Dum1 and Dum2 cover the impact of the first (September 2012) and the second (October 2013) package of fiscal consolidation in Serbia, both of which have included some tax hikes. E-views econometric software is used for data processing. 
However, collected data are subject to certain limitations that need to be briefly commented. The first one is the temporal dimension of the data. Due to numerous political changes, but also because of certain differences in the methodology of gathering and disclosure of data on certain economic phenomena in Serbia, it was not possible to obtain sufficiently long time series for selected (or some related) variables on an annual basis. In addition, National Bank of Serbia has introduced the key policy rate rather late, only in September 2006. Since this rate is a very important link in the process of monetary transmission, it was somewhat counterintuitive to start the analysis before the stated date.

Problems have also emerged regarding the choice of variable which approximates the dynamics of price movements. Since 2009 an official measure of inflation in Serbia is the consumer price index (CPI) and the Statistical Office of Serbia has been publishing it starting from January 2007. On the other hand, data on the retail price index, which preceded $\mathrm{CPI}$, had been published only until December 2010. Having this in mind, CPI was selected, and the only option left for the beginning was - January 2007. Accordingly, in order to obtain the best possible basis for econometric modeling, taking into consideration the short time frame of the data available, the only logical choice was monthly frequency of the data.

Another important remark relates to the choice of variable which approximates the real economic activity. For this purpose it is common to use data on GDP or its growth rate. However, information of this type in Serbia is only available on quarterly and annual basis. Due to this fact, the index of industrial production, which is published at monthly frequency, is selected as a proxy variable. This approximation certainly has its roots in economic theory but is also very common in empirical studies.

Table 1. ADF unit root tests

\begin{tabular}{|l|l|l|l|l|}
\hline \multirow{2}{*}{ Variable } & \multicolumn{2}{|c|}{ Intercept } & \multicolumn{2}{c|}{ Intercept \& Trend } \\
\cline { 2 - 5 } & ADF test & $\mathrm{p}$-value & ADF test & p-value \\
\hline IND & $-2,65$ & 0,0856 & $-2,68$ & 0,2439 \\
\hline $\mathrm{CPI}$ & $-1,52$ & 0,5161 & $-2,67$ & 0,2524 \\
\hline $\mathrm{ER}$ & $-2,51$ & 0,1162 & $-3,11$ & 0,1102 \\
\hline $\mathrm{M}$ & $-1,21$ & 0,6653 & $-0,79$ & 0,9612 \\
\hline $\mathrm{IR}$ & $-1,71$ & 0,4176 & $-3,04$ & 0,1262 \\
\hline$\Delta$ IND & $-12,44$ & 0,0001 & $-12,39$ & 0,0000 \\
\hline$\Delta \mathrm{CPI}$ & $-7,15$ & 0,0000 & $-7,27$ & 0,0000 \\
\hline$\Delta \mathrm{ER}$ & $-5,28$ & 0,0000 & $-5,25$ & 0,0002 \\
\hline$\Delta \mathrm{M}$ & $-13,42$ & 0,0001 & $-13,48$ & 0,0000 \\
\hline$\Delta \mathrm{IR}$ & $-6,74$ & 0,0000 & $-6,71$ & 0,0000 \\
\hline
\end{tabular}

Source: author's calculations 
As described in detail in the methodology section, prior to econometric modeling, it is necessary to determine the level of integration of selected time series. To this end, the appropriate unit roots tests are conducted. Time series Augmented Dickey-Fuller tests (ADF hereafter) for variables in both levels and first differences are reported in Table 1. The lag length is determined according to the Schwartz info-criterion.

As can be seen from the table 1, all time series are stationary in first differences i.e. integrated of the first order, and therefore represent an appropriate basis for examination of possible cointegrating relationships.

\section{Results and Discussion}

After ADF tests have verified that all time series used in this study are integrated of the same (first) order, the analysis continues by applying the Johansen procedure for determining the number of cointegrating vectors. Taking into account the theoretical foundations of the monetary transmission mechanism, as well as the objective of this study, econometric modeling will take place on two fronts. The first model (Model IND hereafter) investigates the impact of monetary variables on real economic activity:

IND = $f(E R, I R, M)$

while the second model (Model CPI hereafter) examines the impact of monetary variables on price level:

$C P I=f(E R, I R, M)$

Optimal number of lags is determined on the basis of multivariate info criteria. Tables 2 and 3 present Akaike (AIC), Schwartz (SC) and Hannan-Quinn (HQ) info criteria values for selected groups of variables. As mentioned earlier, this study prefers to use SC over AIC and HQ in determining lag lengths.

Table 2. Model IND: Lag order selection criteria

\begin{tabular}{|c|c|c|c|}
\hline Lag & AIC & SC & HQ \\
\hline 1 & -10.43109 & $-9.822305^{*}$ & -10.18758 \\
\hline 2 & -10.84570 & -9.749899 & $-10.40739^{*}$ \\
\hline 4 & $-10.86129^{*}$ & -8.791431 & -10.03336 \\
\hline * indicates lag order selected by the criterion, 7 lags originally included, results (without \\
significance) for certain lags are omitted to conserve space.
\end{tabular}

Source: author's calculations 
Jevđović G.: Investigating the Efficiency of Monetary Transmission Channels in Serbia

Table 3. Model CPI: Lag order selection criteria

\begin{tabular}{|c|c|c|c|}
\hline Lag & AIC & SC & HQ \\
\hline 2 & -13.55625 & $-12.46045^{*}$ & $-13.11794^{*}$ \\
\hline 4 & $-13.87502^{*}$ & -11.80517 & -13.04710 \\
\hline \multicolumn{2}{|c|}{$\begin{array}{l}\text { * indicates lag order selected by the criterion, 7 lags originally included, results (without } \\
\text { significance) for certain lags are omitted to conserve space. }\end{array}$} \\
\hline
\end{tabular}

Source: author's calculations

In the next step, possible cointegrating relationships are tested by employing Johansen procedure. This step actually determines the rank of the matrix $\Pi$ which will indicate the (non)existence of a long-term equilibrium relationship among variables. In the case of model IND the so-called standard choice of deterministic components is used - intercept (no trend) in cointegration space, intercept in VECM. However, in the case of model CPI it turned out that both intercept and trend are needed in the cointegration space, but only intercept in VECM. Trace and maximum eigenvalue tests for both studied cases are reported in Tables 4 and 5.

Table 4. Model IND: Johansen's test for multiple cointegrating vectors

\begin{tabular}{|c|c|c|c|c|c|}
\hline No. of CE(s) & Eigenvalue & Trace & Prob. & Max-Eigen & Prob. \\
\hline None & 0.341881 & 53.86409 & 0.0123 & 34.30635 & 0.0059 \\
\hline At most 1 & 0.111792 & 19.55774 & 0.4534 & 9.721068 & 0.7704 \\
\hline At most 2 & 0.085261 & 9.836673 & 0.2935 & 7.307562 & 0.4534 \\
\hline At most 3 & 0.030372 & 2.529111 & 0.1118 & 2.529111 & 0.1118 \\
\hline
\end{tabular}

Source: author's calculations

Table 5. Model CPI: Johansen's test for multiple cointegrating vectors

\begin{tabular}{|c|c|c|c|c|c|}
\hline No. of CE(s) & Eigenvalue & Trace & Prob. & Max-Eigen & Prob. \\
\hline None & 0.380135 & 69.87175 & 0.0144 & 38.73850 & 0.0067 \\
\hline At most 1 & 0.190667 & 31.13325 & 0.4364 & 17.13516 & 0.4464 \\
\hline At most 2 & 0.144926 & 13.99809 & 0.6578 & 12.68194 & 0.3544 \\
\hline At most 3 & 0.016117 & 1.316141 & 0.9953 & 1.316141 & 0.9953 \\
\hline
\end{tabular}

Source: author's calculations

Previous two tables present all the necessary data for the sequential procedure of determining the number of cointegrating vectors. At $5 \%$ significance level, both relevant tests clearly indicate that in both CPI and IND model rank of the matrix $\Pi$ is exactly 1 . In other words, there is a long-term equilibrium relationship between selected monetary variables and real 
economic activity (model IND) i.e. price level (model CPI) which confirms the first hypothesis $(\mathrm{H} 1)$ of this research.

Cointegrating vectors derived from the Johansen procedure (normalized in relation to the variable of interest) are defined by the following equations:

$$
\begin{aligned}
& \text { IND = 0,629225 - 0,181685 ER - 0,008917 IR - 0,350072 M } \\
& \mathrm{t}: \quad(-1,51940) \quad(-4,01099) \quad(-3,50013) \\
& C P I=-2,618550-0,601381 \text { ER }-0,014307 \mathrm{IR}+0,103834 \mathrm{M}-0,008848 \\
& \mathrm{t}: \quad(-4,68559) \quad(-5,65842) \quad(1,54027) \quad(-17,2499)
\end{aligned}
$$

Estimated cointegrating vectors describe the way in which selected monetary variables affect real economic activity and price level in the long run. In particular, according to the results of this study (7), an increase in the exchange rate (depreciation of the domicile currency) by 1 percentage point leads to a decline in real economic activity by 0,18 percentage points. It is evident that such a result is not in line with economic theory which suggests that depreciation of the national currency leads to economic growth, through increase in net-exports. Nevertheless, obtained result can be explained by the fact that depreciation of Serbian Dinar has stronger effect on the quantum of imports than on the quantum of exports. In other words, decrease in prices of domestic goods on foreign markets is not able to initiate a substantial increase in exports, and hence economic activity, because of the modest assortment of goods that are actually exported from Serbia. Thus, importdependent economy can be labeled as the main factor that determines the observed unconventional direction of the exchange rate channel. A similar course of action was recorded in other CEE developing countries (Lang \& Krznar, 2004; Vizek, 2006; Doležaj, 2011, etc).

Regarding the CPI model (8) it can be noted that a 1 percentage point depreciation of the domicile currency leads to a decline in the price level of approximately 0,6 percentage points. This result can also be explained by certain anomalies of the domicile economic system, inter alia high indebtedness of both private and public sector in foreign currency (euro). In these circumstances, national currency depreciation might trigger a fall in aggregate demand and consequently also prices, due to the increase in the burden of debt payments (in national currency). In addition, fear of floating may be a factor that causes excessive responses of monetary policy on depreciation pressures, thus leading to an economic downturn and deflation. This result is also consistent with some previous empirical investigations for the case of neighboring Croatia (Doležaj, 2011, Vizek \& Broz, 2009).

An interesting result is the identified long-term relationship between real economic activity i.e. price level and interest rate. Namely, an increase in interest rate by 1 percentage point leads to the contraction of economic 
activity of about 0,009 percentage points (7) and a decline in prices of approximately 0,014 points (8). Therefore, the interest rate channel in Serbia is very weak, but still exhibits influence which is highly statistically significant and theoretically supported. This is certainly a very encouraging finding for financially and economically underdeveloped Serbia, since the interest rate channel (as elaborated in section 2) is the main form of monetary transmission within the EU.

Finally, a statistically significant pass-through from money supply to real economic activity can be noted from the cointegrating vector (7). Yet, the observed course of action (money supply growth leads to the contraction of economic activity) is not consistent with economic theory. Theoretically. an increase in money supply leads to a decline in interest rate which further encourages investment, aggregate demand and ultimately the real economic activity. Still, if the initial impulse (fall in interest rate) has not occurred, either because the central bank fights inflation with high reference rate, or because banks are unwilling to lend money at lower interest rate (e.g. due to the risk of economic, political or any other nature) or even because the public is not willing to borrow money despite lower cost, the impact on investment spending, and further on economic activity, will certainly fail. On the other hand, identified impact of money supply on price level (8) is consistent with the economic theory.

Based on the cointegrating equations (7) and (8) error correction term is defined, and following VEC models are estimated (tables 6 and 7).

Table 6. VECM for the model IND

\begin{tabular}{|c|c|c|}
\hline Variable & Coefficient & $\mathrm{t}-$ value \\
\hline ECT $_{\mathrm{t}-1}$ & -0.121292 & -1.59113 \\
\hline$\Delta$ IND $_{\mathrm{t}-1}$ & -0.204434 & -1.75610 \\
\hline$\Delta \mathrm{ER}_{\mathrm{t}-1}$ & -0.285342 & -1.50058 \\
\hline$\Delta \mathrm{IR}_{\mathrm{t}-1}$ & -0.000536 & -0.12529 \\
\hline$\Delta \mathrm{M}_{\mathrm{t}-1}$ & 0.122727 & 1.81410 \\
\hline $\mathrm{C}$ & -0.001242 & -0.35890 \\
\hline DUM1 & -0.025627 & -0.83118 \\
\hline DUM2 & -0.012399 & -0.40300 \\
\hline
\end{tabular}

Source: author's calculations

It can be noted (table 6) that an error correction term in VECM for the model IND is statistically significant and has the expected sign. The corresponding coefficient indicates that approximately $12 \%$ of disequilibrium is corrected every month. In other words, it takes about 8 months to reestablish a longterm equilibrium. Among monetary variables only exchange rate and money 
supply have statistically significant impact on the real economic activity in the short run. More precisely, a change in the value of the national currency in the previous month, in terms of 1 percentage point depreciation, is followed by a contraction in economic activity of approximately 1,5 percentage points in the current month. Within a short period, however, this result is consistent with economic theory ( $\mathrm{J}$ curve). Additionally, money supply also has theoretically grounded effect on economic activity. On the other hand, the variable IR does not exhibit a statistically significant effect in the short run, which indicates that the interest rate is less responsible for the short-term fluctuations of real economic activity.

Table 7. VECM for the model CPI

\begin{tabular}{|c|c|c|}
\hline Variable & Coefficient & $\mathrm{t}-$ value \\
\hline$E C \mathrm{~T}_{\mathrm{t}-1}$ & -0.103432 & -3.11058 \\
\hline$\Delta \mathrm{CPI}_{\mathrm{t}-1}$ & 0.204507 & 1.77618 \\
\hline$\Delta \mathrm{CPI}_{\mathrm{t}-2}$ & -0.193589 & -1.61302 \\
\hline$\Delta \mathrm{ER}_{\mathrm{t}-1}$ & -0.140551 & -2.63497 \\
\hline$\Delta \mathrm{ER}_{\mathrm{t}-2}$ & -0.009899 & -0.15456 \\
\hline$\Delta \mathrm{R}_{\mathrm{t}-1}$ & 0.000785 & 0.68676 \\
\hline$\Delta \mathrm{IR}_{\mathrm{t}-2}$ & 0.002138 & 1.97095 \\
\hline$\Delta \mathrm{M}_{\mathrm{t}-1}$ & 0.033367 & 1.53284 \\
\hline$\Delta \mathrm{M}_{\mathrm{t}-2}$ & -0.010611 & -0.50256 \\
\hline $\mathrm{C}$ & 0.006555 & 4.95991 \\
\hline DUM1 & 0.009351 & 1.23099 \\
\hline DUM2 & -0.002674 & -0.35407 \\
\hline
\end{tabular}

Source: author's calculations

VECM for the model CPI is also characterized by statistically significant error correction term. In this case, ECT indicates that about $10 \%$ of disequilibrium is corrected every month - it takes about 10 months for the system to return to the state of the long-term equilibrium. Among monetary variables, a statistically significant impact of the exchange rate from the previous month (t1) and the interest rate from period t-2 are noticeable. Exchange rate channel operates in the same direction as in the long run, but with considerably lower intensity, while the interest rate exhibits almost negligible impact.

Considering all the above mentioned, the evidence presented in this section also confirms the second hypothesis $(\mathrm{H} 2)$ of this study. Exchange rate channel indeed exhibits stronger and more consistent effect on real economic activity and prices, compared to the interest rate channel, and this conclusion applies to both short and long run. 
Finally, in the last step of this research it is necessary to check model specifications, using diagnostic tests. A glance at the correlogram of residuals with no significant peaks of autocorrelation function indicates that there are no significant features of series left outside the model. Darbin-Watson statistic for the model IND ( $D W=1,94)$ and the model $C P I(D W=2,14)$ suggest that there are no issues of first-order serial autocorrelation of residuals. Autocorrelation LM test suggests the same conclusion, including up to lag 12.

Results of White heteroscedasticity test indicate that the assumption of homoscedasticity of variance is not violated in any of the models. Residuals of both models have normal distribution as indicated by Jarque-Bera test statistic ( $\mathrm{JB}=7.74$ for model IND and $\mathrm{JB}=0.53$ for model CPI). CUSUM and CUSUM square tests for both models are shown in Fig. 1 and 2. As can be seen, both cumulative sum of recursive residuals and cumulative sum of squared recursive residuals are generally within the $5 \%$ significant lines, suggesting that residual variance is somewhat stable. Therefore, on the basis of diagnostic tests, it may be concluded that the obtained models have satisfactory features.

Figure 1. CUSUM and CUSUM square tests for the model IND
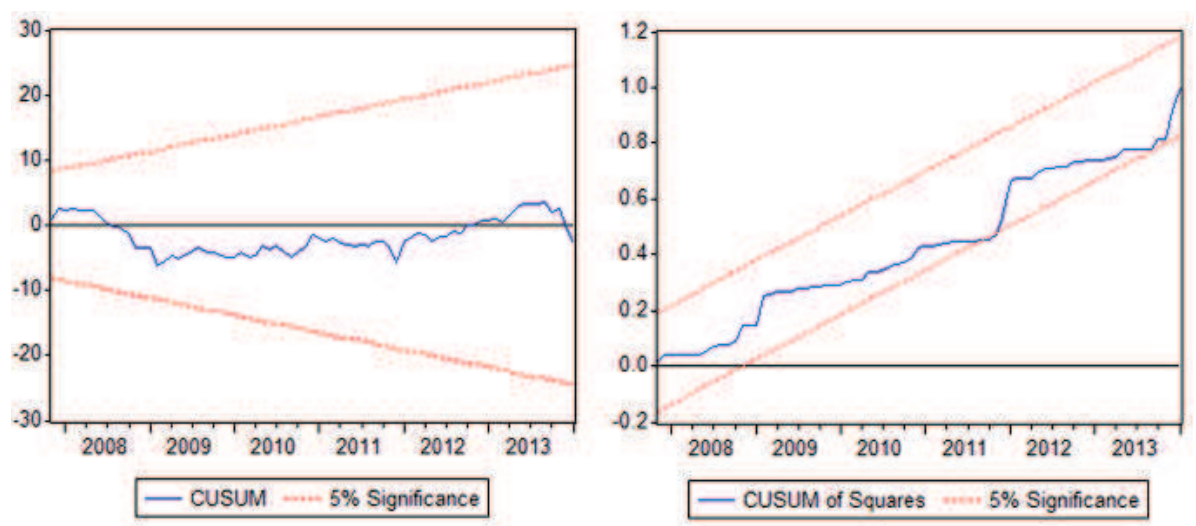

Source: author's calculations 
Jevđović G.: Investigating the Efficiency of Monetary Transmission Channels in Serbia

Figure 2. CUSUM and CUSUM square tests for the model CPI
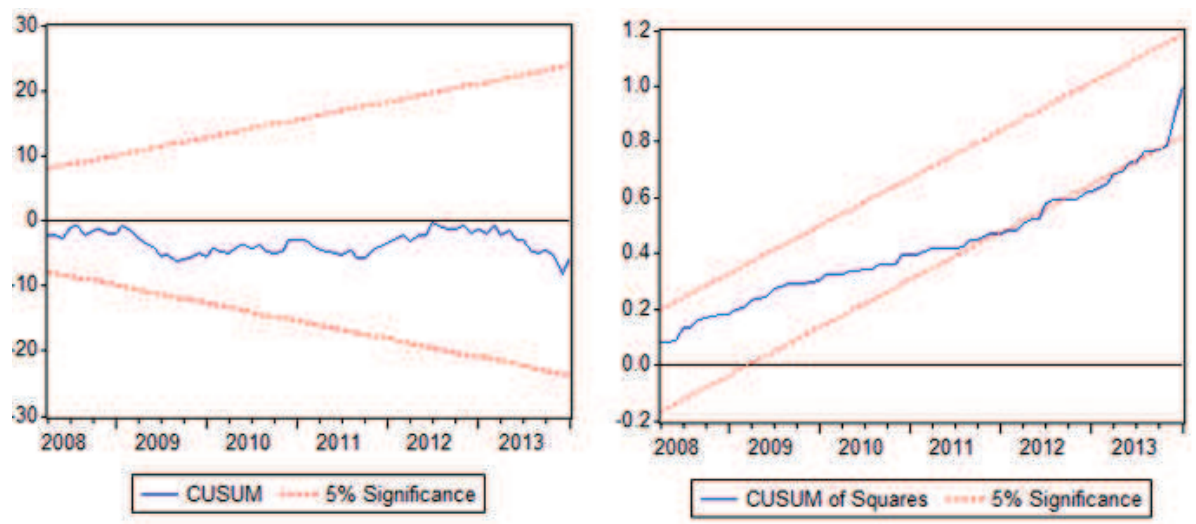

Source: author's calculations

\section{Conclusion}

The aim of this paper was to investigate the efficiency of the monetary transmission mechanism in Serbia. To this end, Johansen cointegration technique based on VAR is used. Time series of selected economic variables have monthly frequency and relate to the period from January 2007 to January 2014.

Results indicate that there is a long-term equilibrium relationship between selected monetary variables (exchange rate, key policy interest rate, money supply) and industrial production as a proxy for real economic activity (model IND). The findings also reveal the existence of a long-term relationship between selected monetary variables and price level (model $\mathrm{CPI}$ ). By interpreting estimated cointegrating vectors and derived vector error correction models, it is highlighted that the exchange rate channel has the strongest impact on both real economic activity and prices in Serbia, regardless of the time frame (short/long run), while in both cases the interest rate channel was substantially weaker. It should be noted that for certain variables identified impact corresponds to theoretical foundations while in some cases an unconventional course of action is identified. However, unusual modus operandi is easily explained by various anomalies of domicile economic system (high degree of informal euroization, import-dependent economy, over-indebtedness of both public and private sector, etc).

Finally, it is essential to briefly comment on certain limitations of this study. First of all, it is a short time frame for which it was possible to gather necessary data. Unavailability of sufficiently long time series is a result of well- 
known reasons (non-comparability of national accounts before and during the transition, war, hyperinflation, territorial disputes etc). In addition, it is important to stress that the analyzed sample relates almost completely to the period of global economic crisis and its spillovers to Serbian economy. Consequently, it may be concluded that this study is limited to the period of economic downturn, noting that different results are possible when the economy is in the phase of expansion. Having this in mind, motives for some further investigations in this field are certainly not lacking.

\section{References}

Acosta-Ormaechea, S., \& Coble, D. (2011). The Monetary Transmission in Dollarized and Non-Dollarized Economies: The Cases of Chile, New Zealand, Peru and Uruguay. Washington: International Monetary Fund. Working Paper No. 11/87. Retrieved from http://www.imf.org/external/pubs/cat/longres.aspx?sk=24804.0

Aleksić, M., Đurđević, L., Palić, M., \& Tasić, N. (2008). Interest Rate Transmission in a Dollarized Economy: The Case of Serbia. National Bank of Serbia. Working Paper No. 15. Retrieved from http://www.nbs.rs/internet/english/90/90 0/

Bernanke, B., \& Gertler, M. (1995). Inside the black box: The credit channel of monetary policy transmission. Journal of economic perspectives, 9(4), 27-48.

Billmeier, A., \& Bonato, L. (2002). Exchange Rate Pass-Through and Monetary Policy in Croatia. Washington: International Monetary Fund. Working Paper No. 02/109. Retrieved from https://www.imf.org/external/pubs/cat/longres.cfm?sk=15869.0

Cevik, S., \& Teksoz, K. (2012). Lost in Transmission? The Effectiveness of Monetary Policy Transmission Channels in the GCC Countries. Washington: International Monetary Fund. Working Paper No. 12/191. Retrieved from https://www.imf.org/external/pubs/cat/longres.aspx?sk=26117.0

Chatelain, B., Generale, A., Hernando, I., Kalckreuth, U., \& Vermeulen, P. (2001). Firm Investment and Monetary Transmission in the Euro Area. Frankfurt am Main, Germany: European Central Bank. Working Paper No. 112. Retrieved from http://www.ecb.europa.eu/pub/scientific/wps/date/html/wps2001.en.html

Doležaj, V. (2011). Efikasnost mehanizma monetarnog prijenosa u Hrvatskoj. Privredna kretanja i ekonomska politika, 21(128), 27-54. Retrieved from http://hrcak.srce.hr/index.php?show=clanak\&id clanak jezik=110023

Erjavec, N., \& Cota, B. (2003). Macroeconomic Granger-Causal Dynamics in Croatia: Evidence Based on a Vector Error-Correction Modeling Analysis. Ekonomski pregled, 54(1-2), 139-156. Retrieved from http://hrcak.srce.hr/index.php?show=clanak\&id clanak jezik=39897

Ganev, G., Molnar, K., Rybinski, K., \& Wozniak, P. (2002). Transmission Mechanism of Monetary Policy in Central and Eastern Europe. Warsaw: Center for Social and Economic Research. Report Case No. 52. Retrieved from http://www.caseresearch.eu/en/node/55096

Jarocinski, M. (2008). Responses to Monetary Policy Shocks in the East and West of Europe: A Comparison. Frankfurt am Main, Germany: European Central Bank. Working Paper No. 970. Retrieved from http://www.ecb.europa.eu/pub/scientific/wps/date/html/wps2008.en.html 
Jevđović G.: Investigating the Efficiency of Monetary Transmission Channels in Serbia

Johansen, S. (1988). Statistical Analysis of Cointegration Vectors. Journal of Economic Dynamics and Control, 12(2-3), 231-254.

Johansen, S. (1991). Estimation and Hypothesis Testing of Cointegration Vectors in Gaussian Vector Autoregression. Econometrica, 59(6), 1551-1580.

Johansen, S., \& Juselius, K. (1990). Maximum Likelihood Estimation and Inference on Cointegration - with Application to the Demand for Money. Oxford Bulletin of Economics and Statistics, 52(2), 169-210.

Johansen, S., \& Juselius, K. (1992). Testing Structural Hypothesis in a Multivariate Cointegration Analysis of the PPP and UIP for UK. Journal of Econometrics, 53(13), 211-244.

Josifidis, K., Allegret, J., \& Beker-Pucar, E. (2009). Monetary and exchange rate regimes changes: The cases of Poland, Czech Republic, Slovakia and Republic of Serbia. Panoeconomicus, 56(2), 199-226. Retrieved from http://scindeks.ceon.rs/article.aspx?query=ISSID\%26and\%267361\&page=1\&sort= 8\&stype=0\&backurl=\%2Fissue.aspx\%3Fissue \%3D7361

Kamin, S., Turner, P., \& Van't Dack, J. (1998). The Transmission of Monetary Policy in Emerging Market Economies. Basel: Bank for International Settlements. Policy Papers No. 3. Retrieved from http://www.bis.org/publ/plcy03.htm

Lang, M., \& Krznar, I. (2004). Transmission Mechanism of Monetary Policy in Croatia. In: Tenth Dubrovnik Economic Conference, Dubrovnik. Retrieved from http://hnb.hr/dub-konf/10-konferencija-radovi/lang-krznar.pdf

Lovrinović, I., \& Benazić, M. (2004). A VAR Analysis of Monetary Transmission Mechanism in the European Union. Zagreb International Review of Economics and Business, 7(2), 27-42. Retrieved from http://hrcak.srce.hr/index.php?show=clanak\&id clanak jezik $=56300$

Malešević-Perović, L. (2009). Kointegracijski pristup analizi inflacije u Hrvatskoj. Financijska teorija i praksa, 33(2), 201-218. Retrieved from http://hrcak.srce.hr/index.php?show=clanak\&id clanak jezik=62555

Mladenović, Z., \& Nojković, A. (2011). Analiza vremenskih serija : Primeri iz srpske privrede. Beograd: Centar za izdavačku delatnost Ekonomskog fakulteta.

Mladenović, Z., \& Nojković, A. (2012). Primenjena analiza vremenskih serija. Beograd: Centar za izdavačku delatnost Ekonomskog fakulteta.

Peersman, G., \& Smets, F. (2001a). Are the Effects of Monetary Policy in the Euro Area Greater in Reccesions than in Booms?. Frankfurt am Main, Germany: European Central Bank. Working Paper No. 52. Retrieved from http://www.ecb.europa.eu/pub/scientific/wps/date/html/wps2001.en.html

Peersman, G., \& Smets, F. (2001b). The Monetary Transmission Mechanism in the Euro Area: More Evidence from VAR Analysis. Frankfurt am Main, Germany: European Central Bank. Working Paper No. 91. Retrieved from http://www.ecb.europa.eu/pub/scientific/wps/date/html/wps2001.en.html

Tasić, N. (2008). Pass-Through of Exchange Rates to Prices in Serbia: 2001-2007. National Bank of Serbia. Working paper No. 10. Retrieved from http://www.nbs.rs/internet/english/90/90 0/

Tkalec, M., \& Vizek, M. (2009). The Impact of Macroeconomic Policies on Manufacturing Production in Croatia. Privredna kretanja i ekonomska politika, 19(121), 61-93. Retrieved from http://hrcak.srce.hr/index.php?show=clanak\&id clanak jezik $=74466$

Van Els, P., Locarno, A., Morgan, J., \& Villetelle, J. (2001). Monetary Policy Transmission in the Euro Area: What Do Aggregate and National Structural Models 
Jevđović G.: Investigating the Efficiency of Monetary Transmission Channels in Serbia

Tell Us?. Frankfurt am Main, Germany: European Central Bank. Working Paper No. 94. Retrieved from

http://www.ecb.europa.eu/pub/scientific/wps/date/html/wps2001.en.html

Vilaret, S., \& Palić, M. (2006). Exchange rate pass-through effect on prices in Serbia. National Bank of Serbia. Working Paper No. 5. Retrieved from http://www.nbs.rs/internet/english/90/90 0/

Vizek, M., \& Broz, T. (2009). Modelling Inflation in Croatia. Emerging Markets Finance and Trade, 45(6), 87-98.

Vizek, M. (2006). Ekonometrijska analiza kanala monetarnog prijenosa u Hrvatskoj. Privredna kretanja i ekonomska politika, 16(109), 29-61. Retrieved from http://hrcak.srce.hr/18348

Eurostat, official webpage. Retrieved from http://ec.europa.eu/eurostat/home

Statistical Office of the Republic of Serbia, official webpage. Retrieved from http://webrzs.stat.gov.rs

National Bank of Serbia, official webpage. Retrieved from http://www.nbs.rs 